\title{
Design Criteria of Learning Space for Street Children: The Observe Rituals Method
}

\author{
Faniah Shafira Amir Ishak, Asri Dinapradipta dan Fransiscus Xaverius Teddy Badai Samodra \\ Department of Architecture, Institut Teknologi Sepuluh Nopember, Surabaya \\ e-mail: asdina_p@arch.its.ac.id
}

\begin{abstract}
Abstrak - An essential dimension for street children in coaching and learning in urban areas like Surabaya is the independence of learning in individual street children who are related to their privacy needs. Awareness of these privacy needs can be done with a perception approach that will vary from one person to another. The appropriate form of architecture as an attempt to deal with the problem of street children in Surabaya is a learning space. The main target and scope of the learning space are in the city of Surabaya, with a dense urban range and high economy. The method used in the search for design criteria is the observe rituals method. The process starts by observing and recording in detail the various events in a setting. Search for design criteria in this study as data to be implemented in a forcebased framework, which is then reviewed to produce a learning space architecture design. The movement and performance of children in the learning process is a significant factor in the search for learning space design criteria. The results showed that moveable, active, open, theatrical, and excited were essential factors to produce design criteria.
\end{abstract}

Kata Kunci-Independence of Learning, Movement, Performance, Privacy.

\section{INTRODUCTION}

$\mathrm{T}$ HE problem regarding street children is one of the phenomenon problems faced by Indonesia. In handling street children, the Government of Indonesia has various necessary regulations. In addition to these regulations, the Indonesian government also has various programs provided to street children. However, the variety of programs does not affect the stage of social change in street children. Street children are not involved in the planning and decisionmaking process regarding empowerment, so there is no sharing of knowledge activities that ultimately, street children cannot develop their mindsets well. Not only official NGOs but small social communities are also very critical in voicing about how to meet the needs of access to education for street children in Surabaya. Therefore, coaching facilities in handling street children in Surabaya are needed. The appropriate form of architecture as an attempt to deal with the problem of street children in Surabaya is a learning space. The learning space has the primary target and scope in the city of Surabaya. The city of Surabaya is a relatively dense urban sphere with quite high movement and economy.

The main factor that needs to be improved is the independence of learning in each street child. Learning independence is a particular attitude that is obtained cumulatively during development. Learning independence is a learning skill that, in the individual's learning process is

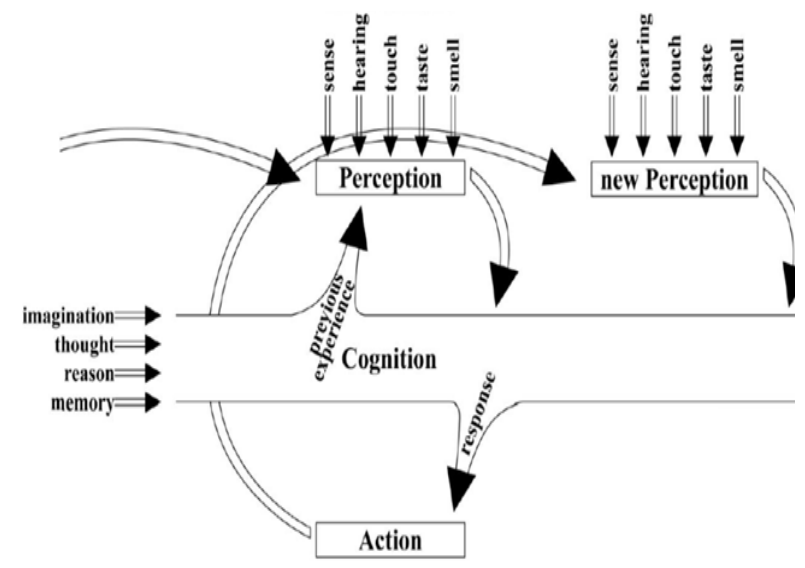

Figure 1. The relationship between perception and cognition.

Table 1.

Observation of movement

\begin{tabular}{ll}
\hline \hline \multicolumn{2}{l}{ Move, categorized as follows: } \\
\hline Moveable Mobile & easy to move \\
Turbulent & agile \\
Lively & spinning, turning \\
Busy & agile \\
Restless & occupied \\
Changeable & uneasy \\
Active & changeful, inconstant \\
Shifting & enterprising, aggressive, energetic \\
Bustling & moving, changing \\
& hustle \\
\hline
\end{tabular}

Table 2.

Observation of performance and practice room

Performance and rehearsal space, categorized as follows:

\begin{tabular}{ll}
\hline Focused & Concentrate \\
Open & Overt \\
Charged & be imposed \\
Intimated & frighten \\
Theatrical & drama \\
Playful & cheerful \\
Mellow & soft \\
Shy & blushful, coy \\
Nervous & twitchy \\
Excited & passionate \\
\hline
\end{tabular}

encouraged, controlled, and assessed by himself [1]. Individuals will continue to learn to be independent in facing various environmental situations so that individuals will eventually be able to think and act on their own. Independence can make someone choose his life path to be able to develop better. Learning independence has a strong influence on learning outcomes, where the learning outcomes determine the quality of learning [2]. Street children have a low level of gaining independence. Little awareness will develop training materials that are owned and the lack of 
The $6^{\text {th }}$ International Seminar on Science and Technology (ISST) 2020

July $25^{\text {th }}$ 2020, Institut Teknologi Sepuluh Nopember, Surabaya, Indonesia

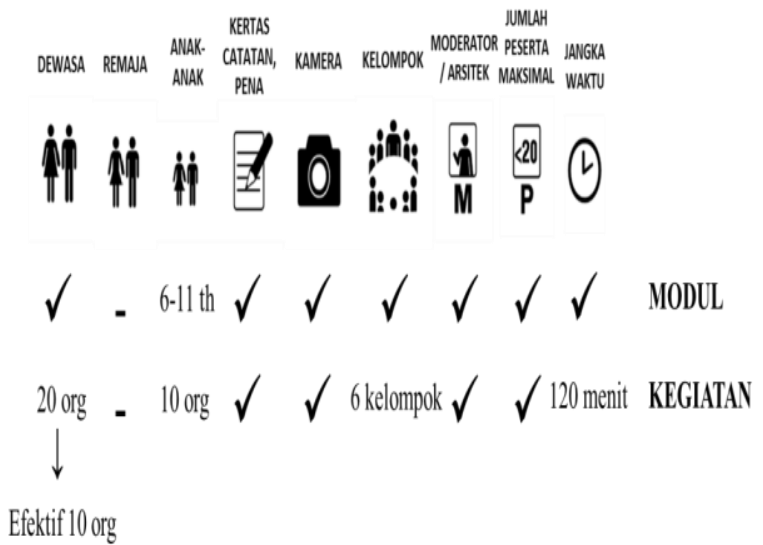

Figure 2. Application of modules and activities carried out during the observation process.
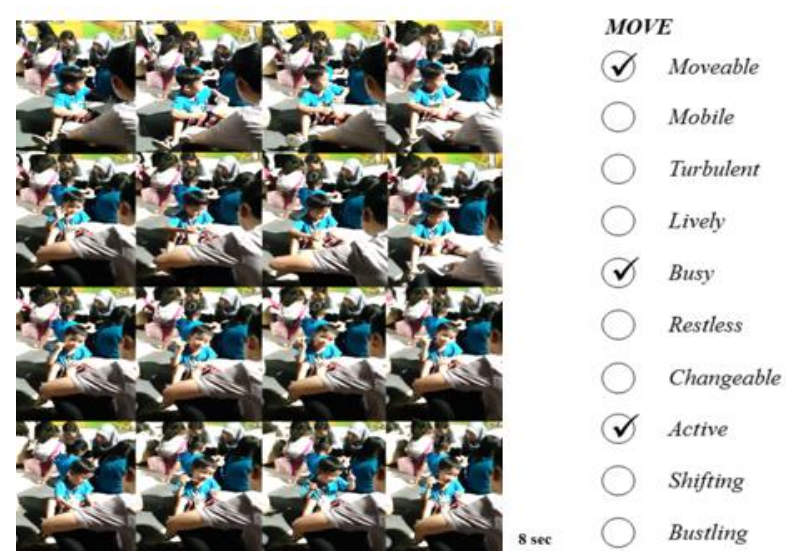

Figure 3 . The process of observing a movement.
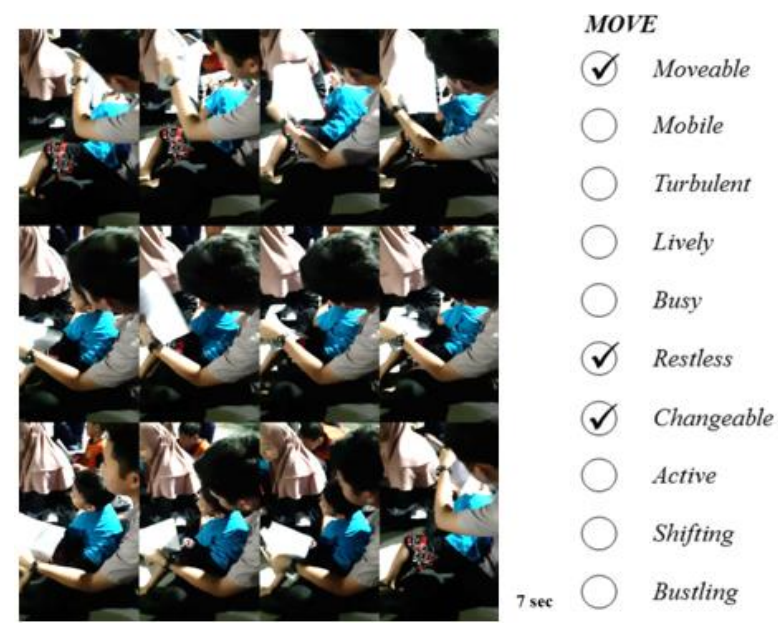

Figure 4 . The process of observing a movement.

street children who have the knowledge to learn. The learning space for street children physically accommodates their need for space. Behavior learning space plays a role in the formation of space programs and architectural forms that approach the behavior of street children. Avoiding failures that allow street children do not need learning; it requires a more approach to the perception of privacy in the act of street children.

Responding to the independence dimension of learning in street children with a tendency to change buildings following the perception of the behavior of street children is very important to realize success in handling street children in
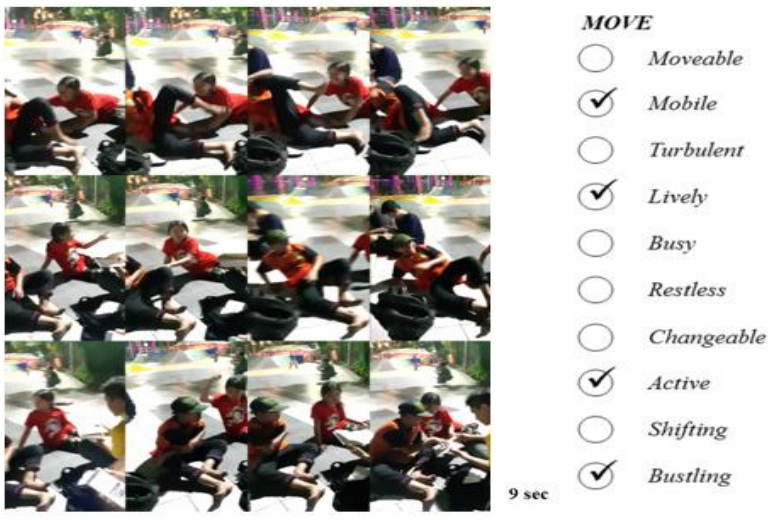

Figure 5. The process of observing a movement

Table 3.

Observation of movement

\begin{tabular}{lll}
\hline \multicolumn{3}{c}{ Observation of movement } \\
\hline Move, categorized as follows: & & \\
\hline Group 1 : & & \\
Time: Beginning (start teaching and & 1 & Moveable \\
learning activities) & 2 & Busy \\
$1 \quad$ student & 3 & Active \\
$1 \quad$ teacher & 1 & Moveable \\
Time: End (finished teaching and & 2 & Restless \\
learning activities) & 3 & Changeable \\
$1 \quad$ student & & \\
Group 2: & & \\
Time: Beginning-end (during teaching & 1 & Mobile \\
and learning activities) & 2 & Lively \\
$2 \quad$ student & 3 & Active \\
1 teacher & 4 & Bustling \\
Conclusion : & & \\
Moveable & Highest \\
Active & & \\
Busy & & \\
Restless \\
Changeable \\
Lively \\
Bustling
\end{tabular}

Surabaya. It is essential for functional integration and mutual influence between learning spaces with learning independence and the perception of privacy in behavior that is inherent to the characteristics of street children. The learning space can respond to the perception of privacy contained in the patterns of interaction of street children, street children educators, and architect's knowledge of architecture for street children. Encourage the dimension of independence of learning and increase interest in learning without boxing the way street children adapt to their environment. The application of the privacy perception approach to the learning behavior of street children can be made with specific observational methods to produce design criteria that can be applied to the design of learning spaces.

\section{THEORY/RESEARCH METHODS}

\section{A. Perpection of Privacy}

Perception can be easily defined as a cognition subsystem but also as a process of cognition (Figure 1). To connect the concept of perception with architectural theory, it must extract certain aspects of the concept that are adequate. The point of view tends to be different; the concept of perception 
The $6^{\text {th }}$ International Seminar on Science and Technology (ISST) 2020

July $25^{\text {th }} 2020$, Institut Teknologi Sepuluh Nopember, Surabaya, Indonesia

Tabel 4.

Observation of performance and practice room

\begin{tabular}{|c|c|c|}
\hline \multicolumn{3}{|c|}{ Performance and rehearsal space, categorized as follows : } \\
\hline \multicolumn{3}{|c|}{ Group 1: } \\
\hline Time: Beginning-end (during teaching & 1 & Focused \\
\hline and learning activities) & 2 & Open \\
\hline 1 student & 3 & Theatrical \\
\hline 9 student & 4 & Playful \\
\hline all teachers & 5 & Excited \\
\hline Time: Beginning-end (during teaching & 1 & Open \\
\hline and learning activities) & 2 & Charged \\
\hline 2 student & 3 & Intimate \\
\hline 8 student & 4 & Theatrical \\
\hline all teachers & 5 & Excited \\
\hline \multicolumn{3}{|l|}{ Conclusion : } \\
\hline Open & \multicolumn{2}{|c|}{ Highest } \\
\hline \multicolumn{3}{|l|}{ Theatrical } \\
\hline \multicolumn{3}{|l|}{ Excited } \\
\hline Focused & \multirow{4}{*}{\multicolumn{2}{|c|}{ Lowest }} \\
\hline Playful & & \\
\hline Charged & & \\
\hline Intimate & & \\
\hline
\end{tabular}

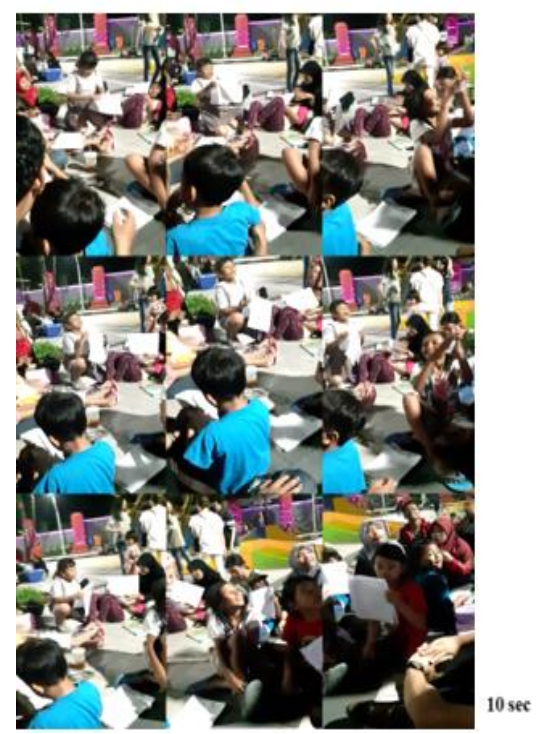

PERFORMANCEAND REHEARSAL SPACE

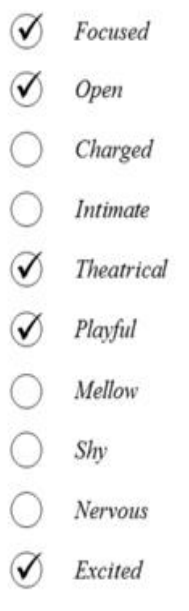

Figure 6 . The process of observing performance and practice room.

is sorted as follows: creator of space $\rightarrow$ space $\rightarrow$ user of space. That means that the space created by the architect will become a reality and will then be felt by the user. This space will play a new spatial paradigm that reminds users how they should behave and use those spaces, who will do what, when, and with whom [3].

According to Altman, privacy is a process of selective control of access to oneself and access to others. Control is like, the distance at which humans move [3]. As for some privacy functions, the first function of privacy is the regulator and authority of interpersonal interactions, which means the extent to which relationships with others are desired, when it's time to be alone and when it's time to be with other people. Privacy is divided into two types, namely low privacy (occurs when relationships with others are desired), and high privacy (occurs when wanting to be alone and relationships with others are reduced). The second function of privacy is to plan and make strategies to connect with others, which includes

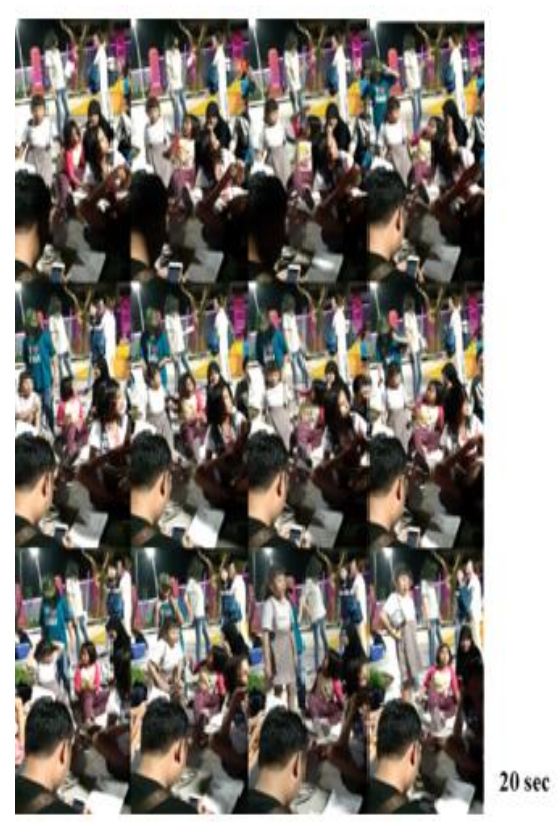

PERFORMANCEANL REHEARSALSPACE

Figure 7. The process of observing performance and practice room

intimacy/distance in dealing with others. The third function of privacy is to clarify self-identity. The factors that influence privacy are divided into three, namely, personal factors, situational factors, cultural factors.

\section{B. Method}

The participatory design method, after the theoretical approach and precedent study, uses the users' everyday life method modules to analyze the observations [4]. To observe and record details of the user's daily life, here are five ways, namely, move in, experience everyday locations, observe rituals, share favorite locations, journeys of discovery. To observe and record in detail the various events in a setting, the method chosen, namely the technique of observing rituals [4] contains Observe all events and activities (their behavior towards a setting) within a specific time (when calm, busy, listening, doing, chatting, etc.), Organize the photos taken and adjust the spatial quality and time, Give an explanation that represents the atmosphere that was captured.

Observation, or somewhat routine monitoring and documentation of users (users), forms the second relevant category of module methods for the participatory design process. One option, for example, is to accompany users in their daily lives and to record different events to conclude concerning architecture. This observation may require the long-term monitoring of a group to get more specific and reliable results about their personal preferences. Another method is to not only accompany or interview users but also invite them to reflect on their daily lives, by presenting and documenting their location. That is because if attending and observing users in an environment, they do not know can ignore typical daily behavior. The purpose of observing the user's daily life is to study their daily environment. Findings from observations are integrated into design work and, at the same time, form the basis of further communication between architects and users. Exploration from observations of the 
The $6^{\text {th }}$ International Seminar on Science and Technology (ISST) 2020

July $25^{\text {th }} 2020$, Institut Teknologi Sepuluh Nopember, Surabaya, Indonesia

user's daily life helps eliminate stereotypes on both sides. In any case, this presents an expansion of designer knowledge.

\section{RESULT AND DISCUSSION}

Choosing to use the observe rituals method, that is, seeing movement and performance (Table 1, Table 2) when teaching and learning activities last for 120 minutes (Figure 2, Figure 3, Figure 4, Figure 5, Figure 6, Figure 7). Observation results from the movement with the observe rituals method (Table 3 ): Observation results from the performance and practice room with the observe rituals method (Table 4):

\section{CONCLUSION}

The design criteria obtained from the search for criteria for street children learning spaces with the observe ritual method using the perception of privacy approach are summarized as follows:(1)Moveable: Requires area that is easily accessible between one room and another, requires space with a more straightforward but still dynamic sequence; (2)Active: Requires circulation that does not confuse children; (3)Open: Requires an area that is used as a special place for interludes other than the main room; (4)Theatrical: Requires space for the development of children's skills, requires space to stimulate children's thoughts and motor skills that are visually connected, requires interactive and communicative space with children, with architectural elements as the medium; (5)Excited: Requires space with visualization related to the play of colors and numbers, requires a gathering space that children use for proper socializing.

\section{ACKNOWLEDGMENT}

The author would like to thank the Save Street Child Surabaya community, all of the teaching staff, and the independent children of Save Street Child Surabaya, who were willing to be the main speakers in this research.

\section{REFERENCES}

[1] S. Lilik, W. Djannah, dan Wagimin, “ Tingkat Penguasaan SelfRegulated Learning Skills Ditinjau Dari Segi Prestasi Belajar dan Lama Studi Pada Mahasiswa FKIP UNS," Jurnal Conselium, vol. 1, no. 1, 2012.

[2] S. Yanti, dan E. Surya, Kemandirian Belajar Dalam Memaksimalkan Kualitas Pembelajaran, Medan: Prodi Pendidikan Matematika, PPs Unimed, 2017.

[3] I. Altman, The Environment \& Social Behavior, Privacy, Personal Space, Territory, Crowding, Monterey: Brooks/Cole publishing company, 1975.

[4] S. Hofmann, Architecture is participation, Berlin: Jovis, 2014. 